\title{
Ecological design based on bio-models in sustainable urban development
}

\author{
Tatiana Tsitman $^{l^{*}}$, and Kseniia Proshunina ${ }^{1}$ \\ 1 Astrakhan State University of Architecture and Civil Engineering, 414056, st. Tatishcheva, \\ Astrakhan, Russia
}

\begin{abstract}
The article considers the possibilities of a new environmental approach to design. Nature presents us with such opportunities. Evolution has led to an environmentally friendly solution to the interaction of the body and its environment. Currently, architects and engineers are trying to solve the processes of environmental design approaches. It is enough to see these solutions in the bio model, to determine the laws of existence for applying its qualities in the shaping of the designed architectural object in the environment. The application of the mechanisms of functioning of the bio model will be distinguished by the originality of engineering work and aesthetic diversity. The formation of the concept allows you to simulate the architectural and environmental space for a specific environment. The uniqueness of the natural environment component explains the typical design decisions for specific environmental conditions. Bio models of the Astrakhan region considered to identify environmental design methodology. An analysis of the methods for adapting bio models to the landscape and climatic conditions of the considered area and their growth is necessary for the application of these methods in architectural shaping and engineering and technical support of the designed facility for specific conditions of the city of Astrakhan.
\end{abstract}

\section{Introduction}

The modern age has entered a new era - the development of information technology and global digitalization. As a result, world communities began to formulate problems that

\footnotetext{
*Corresponding author: taortsi@gmail.com
} 
affect not only certain types of society, countries, and continents but relate to world problems formed over the course of human existence. Manmade architecture created by humankind, the formation of a new landscape pleasing to man, and as a result, we received the negative effects of anthropogenic factors that destroy the natural component of the ecosystem of our planet.

The topic of changes in the ecosystem is currently relevant and actively discussed; many scientists are concerned about fundamentally new approaches to using the planet's resources, reducing the impact of anthropogenic factors, new positions on effective construction and a new imitation of life in a comfortable sustainable urban development. In addition, the typification and unification of products and materials in industrial and civil construction has developed a kind of architectural model of buildings, which is standard for many countries. Such a "standard model" deprives the uniqueness of the city, historically formed within the boundaries of territorial allotments, characterized by personal climate indicators, natural landscape, and valuable historical and architectural environment, emphasizing the uniqueness of urban development. These buildings are far from perfect, not working in a single relationship with the natural environment, worsen the individual microclimate and violate the video ecology and unique image of the city [1].

World tendencies in the field of construction are oriented towards the natural component and are called upon to form a new "Green Architecture", mastering the energy of nature like a plant world. We can say that plants are natural architectural structures. Like human housing, they are tied to one place, they have to look for the optimal survival strategy in this region, over millions of years they have developed a set of solutions that have been constantly improving from generation to generation.

The solution to the new approach to environmental design is obvious; plants demonstrate it and such design will be unique for territories anywhere in the world. It is enough to study the prevailing conditions, analyzing the protobiomodel, and determine the laws of its existence for the shaping of the designed architectural object in the environment, primarily due to the functions of its vital functions, the necessary elements that ultimately determine its appearance and give insights into the beauty of the bioform.

Research in this area goes far back centuries since a person studied the world around him. A huge research base was laid in the structure of the ancient Acropolis. The system of its proportioning takes into account the rules of the "golden section", reflected in the laws of morphogenesis of plant and natural organisms. An outstanding figure of the 16th century, Leonardo da Vinci, revealed experimental models of technical inventions and architectural elements when borrowing bionic forms [2].

In the nineteenth century, Joseph Paxton used forms of nature. Paxton was an architect and botanist. At the world exhibition in London, he presented a model of the crystal palace in Hyde Park. The project was based on a model of leaves of a tropical plant Victoria Amazon. Like the veins of a plant and a thin sheet between them, the architect erected a structure represented by a frame made of modular metal and wooden elements with the easy filling of glass. 
In the late nineteenth and early twentieth centuries, the architect Antonio Gaudi developed the principles of zoomorphic forms in the direction of the architectural style "Modern". He managed not only to easily apply the properties of natural forms in design but also to create a unique image of Barcelona, using new building materials and technologies to create artificial elements, new designs, and structures, following the forms of wildlife. The color, texture and graceful curves of the lines piercing the city create to this day the impression of incredible integrity with the environment and universal harmony.

In the twentieth century, a new science "ergonomics" arises, which defines the possibilities of the competent provision of the process and means of labor for humans. Based on specific experimental studies of ergonomics, industrial prototypes and products with prevailing gravitation of forms close to organic appear. At the end of the 20th century, the term "biomimicry", which appeared back in the 16th century, is undergoing new development, inspiring architects and engineers to implement new eco-friendly developments. Research in the field of biomimicry began by Janine Benius, highlighting the main levels of imitation: the shape of the body; mechanisms or processes of the functional existence of the body; ecosystems [3,4].

Actualization and propaganda of Green Architecture technologies are being massively introduced into the sphere of intellectual construction. During the construction of capital construction objects in the 21 st century, compliance with environmental safety standards is encouraged, and a certification procedure for buildings is introduced. Certification systems take into account energy efficiency indicators, the quality and environmental friendliness of the materials used, waste reduction, and the further environmental impact of the construction site. In the field of architectural and construction areas, the focus on the environmental component was supported by leading professionals and theoreticians.

The following works became the theoretical base of domestic modern research in the field of environmental design: Doctors of architecture Iovlev V.I. "Ecological foundations of the formation of architectural space (on the example of the Urals)", which displays the methodology for the formation of ecological spaces [5,6]; Doctors of technical sciences Ilyichev V.A., Kolchunov V.I., considering the design of settlements from the perspective of biosphere compatibility [7]; Doctors of technical sciences Belko T.V. "Nature. Art. Design", which describes the principles of morphogenesis from a bionic organism [8].

The aim of the study was the formation of the concept of architectural and ecological space and the creation of an eco-model for use in the city of Astrakhan.

To achieve this goal, the following tasks were formulated:

1. to analyze the climatic characteristics of the Astrakhan region;

2. to perform bionic studies of selected natural forms;

3. to apply the principles of bionic modeling in the formation of structural elements of the architectural form;

4. the formation of techniques and methods for use in a specific urban environment;

5. The proposal of the way to implement turnkey solutions in the current urban environment. 
The shaping in the existing urban environment should be in harmony with the structure and climatic features, and meet the modern requirements of sustainability, like the plantnatural world, rich in its uniqueness and formed in its characteristic habitat. Just as plants have a process of adaptation, with adaptation to the environment due to their appearance and internal life processes, the modern architectural environment must be adapted to fit into the conditions of a particular city, adapting to external factors.

Application of the project approach in the specific conditions of the Astrakhan region based on the local bio model of the plant component will allow creating a unique ecological design of the projected object. Such a symbiosis with the biosphere of urban space will form a sustainable urban development of the designed environment.

\section{Materials and methods}

Landscape-spatial structures and climate are the main factors influencing the formation of architectural space. Such a combination can be represented in the likeness of woven spatial matter and the influence within it of the totality of environmental influences and phenomena. In a simplified interpretation of the presented model of a piece of the planet's earth's surface, life developed, adapted to specific conditions and forming stable forms of dwellings throughout history. Identification of cause-effect and eco-model design of formations will allow us to trace the potential relevant to ecosystem design.

The Astrakhan region was chosen as an example of conducting such an experiment. The territory is characterized by difficult climatic conditions: high temperatures, up to $41 \mathrm{o}$ in the summer, an extended warm period, a small amount of rainfall. Clay soil, not enriched with hummus. Plants adapt on poor saline soils, respectively, natural landscapes and vegetation have their own unique characteristics, mechanisms and morphological formations of which can be used in architectural design [9].

With a detailed study of the structures of biological plant organisms, a methodology has been formed for creating ecological design objects based on a bio model. The methodology is structured and divided into stages.

The bionic study of the selected bio model, its adaptive properties to the climate and habitat is primarily carried out. Nature is incredibly organic, no-frills, everything determines a specific function, and more often several functions at the same time. For analysis, a model is selected that is able to answer questions for the organization of space, the properties of which will help improve the quality of environmental design, increase the comfort of the space, and at the same time remain in harmony with the natural component.

In the study of vegetation in the Astrakhan region, the main characteristic is their life form - a method of adaptation to natural and climatic conditions that affect their appearance and structure. The developed features in the process of adaptation are the basis of architectural shaping.

An analysis of the territory of the Astrakhan Territory led to its division into three natural types of habitat - desert, floodplain, and marine. Desert habitats are characterized by 
a lack of moisture, soil salinization, wind, and consequently soil mobility (sand), a sharp change in climatic periods. Under the influence of these factors, characteristic signs of the plant structure were formed, leading to a reduction in the evaporation surface, as a result of such adaptation, the formation of plants on the surface: spines; a thick cuticle, representing a structureless film covering leaves and stems; pubescence, in the form of a light structure of small elements of hairs forming a dense cover; light branching design, which also allows you to defend against the wind and maintain moisture conditions; mechanical strengthening of shoots, in the form of a developed root system, to which plants can be attributed, such as silver goof, thistle, Tamarix multi-branched, etc.

The following structural features are characteristic of the floodplain and marine habitats: a straight simple stalk, usually with a hollow air cavity inside; a strong, light and flexible shoot; to plants of this kind can be attributed reeds and brambles; leaves with a developed membrane network, such as lotus; the rigid structure of the leaves of underwater plants, often containing lime inclusions in the organics, coated with a water and gasimpermeable cuticle, watermelon (Rapa natans) can be attributed to such a plant; flattened leaves have algae.

Description of the most characteristic species, life forms, adaptation and characteristics of functioning are indicated in Table 1.

Table 1. The vegetation of the Astrakhan region.

\begin{tabular}{|c|c|c|c|c|}
\hline Namelimage & $\begin{array}{c}\text { Nature } \\
\text { of the } \\
\text { place }\end{array}$ & $\begin{array}{c}\text { Adaptation } \\
\text { characteristi } \\
\text { cs } \\
\end{array}$ & $\begin{array}{c}\text { Structure / } \\
\text { Architectur } \\
\text { al Form } \\
\end{array}$ & $\begin{array}{c}\text { Innovative } \\
\text { technologies }\end{array}$ \\
\hline \multicolumn{5}{|c|}{ Steppe plants } \\
\hline $\begin{array}{l}\text { Steppe Sagebrush - perennial grasses } \\
\text { and shrubs with a thick ligneous root } \\
\text { [10]. }\end{array}$ & $\begin{array}{c}\text { Especi } \\
\text { ally } \\
\text { commo } \\
\mathrm{n} \text { in } \\
\text { Central } \\
\text { Asia, } \\
\text { and } \\
\text { begin } \\
\text { already } \\
\text { beyond } \\
\text { the } \\
\text { Volga, } \\
\text { from } \\
\text { Astrak } \\
\text { han }\end{array}$ & $\begin{array}{l}\text { Moisture - } \\
\text { resistant } \\
\text { plant can } \\
\text { exist for a } \\
\text { long time } \\
\text { without } \\
\text { water, } \\
\text { pubescent } \\
\text { flowers and } \\
\text { leaves create } \\
\text { a crown that } \\
\text { protects from } \\
\text { the sun. } \\
\text { Color silver - } \\
\text { reflects the } \\
\text { sun well }\end{array}$ & $\begin{array}{l}\text { Structure of } \\
\text { the leaves is } \\
\text { rhythmically } \\
\text { consistent; } \\
\text { the upper } \\
\text { pubescence } \\
\text { creates a } \\
\text { closed } \\
\text { coating. }\end{array}$ & $\begin{array}{c}\text { Pubescent } \\
\text { structure of } \\
\text { inflorescenc } \\
\text { es - } \\
\text { structural } \\
\text { coatings for } \\
\text { protection } \\
\text { against the } \\
\text { sun, a } \\
\text { hollow stem } \\
\text { saves water, } \\
\text { silver color } \\
\text { for solving } \\
\text { facade } \\
\text { systems, } \\
\text { fencing - a } \\
\text { reflection of } \\
\text { sunlight. }\end{array}$ \\
\hline
\end{tabular}




\begin{tabular}{|c|c|c|c|c|}
\hline Namelimage & $\begin{array}{c}\text { Nature } \\
\text { of the } \\
\text { place }\end{array}$ & $\begin{array}{c}\text { Adaptation } \\
\text { characteristi } \\
\text { cs }\end{array}$ & $\begin{array}{c}\text { Structure / } \\
\text { Architectur } \\
\text { al Form }\end{array}$ & $\begin{array}{c}\text { Innovative } \\
\text { technologies }\end{array}$ \\
\hline $\begin{array}{l}\text { Tamarix. A tall, sprawling shrub with } \\
\text { reddish young shoots. The leaves are } \\
\text { narrow, awl-shaped. Pink flowers are } \\
\text { collected in loose, panicles, with the } \\
\text { ability to have flowering plants } \\
\text { throughout the entire warm period. } \\
\end{array}$ & $\begin{array}{l}\text { Grows } \\
\text { on } \\
\text { solonc } \\
\text { hak } \\
\text { soils } \\
\text { along } \\
\text { the } \\
\text { banks } \\
\text { of } \\
\text { rivers, } \\
\text { lakes, } \\
\text { and } \\
\text { estuari } \\
\text { es. } \\
\text { Mostly } \\
\text { along } \\
\text { rivers, } \\
\text { on salt } \\
\text { marshe } \\
\text { s and } \\
\text { salt }\end{array}$ & $\begin{array}{c}\text { Drought- } \\
\text { resistant, not } \\
\text { picky about } \\
\text { the soil, } \\
\text { photophilous, } \\
\text { has special } \\
\text { properties by } \\
\text { which salts } \\
\text { are brought } \\
\text { out, is } \\
\text { distinguished } \\
\text { by a variety } \\
\text { of colors of } \\
\text { flowers and } \\
\text { foliage. Form } \\
\text { complexes } \\
\text { with plant } \\
\text { communities. }\end{array}$ & $\begin{array}{c}\text { Spreading } \\
\text { interwoven } \\
\text { branches } \\
\text { with } \\
\text { delicate } \\
\text { greenery } \\
\text { and very } \\
\text { colorful } \\
\text { flowers } \\
\text { form the } \\
\text { frame of the } \\
\text { bush. } \\
\text { Formation } \\
\text { of an } \\
\text { integrated } \\
\text { array of } \\
\text { modular } \\
\text { units. }\end{array}$ & $\begin{array}{c}\text { Weaving } \\
\text { branches- } \\
\text { wind } \\
\text { protection- } \\
\text { (formation } \\
\text { of facade } \\
\text { screens) } \\
\text { The sheet } \\
\text { structure } \\
\text { retains } \\
\text { moisture- } \\
\text { structural } \\
\text { slabs for } \\
\text { cooling } \\
\text { facades, } \\
\text { Creates a } \\
\text { shadow and } \\
\text { protects the } \\
\text { plant against } \\
\text { the sun - } \\
\text { sunscreens. }\end{array}$ \\
\hline $\begin{array}{l}\text { Elaeagnus commutata. A small tree } \\
\text { with a developed strong rhizome, } \\
\text { which leaves are simple, arranged } \\
\text { alternately, oval or ovate-lanceolate, } \\
\text { [10]. Fruit - drupe, spherical or ovoid. }\end{array}$ & $\begin{array}{l}\text { marshe } \\
\text { s, } \\
\text { along } \\
\text { the } \\
\text { edges } \\
\text { of } \\
\text { moats, } \\
\text { and } \\
\text { someti } \\
\text { mes on } \\
\text { sand } \\
\text { dunes, } \\
\text { clay } \\
\text { steppe } \\
\text { soils. }\end{array}$ & $\begin{array}{l}\text { Frost- } \\
\text { resistant, due } \\
\text { to the } \\
\text { developed } \\
\text { rhizome, the } \\
\text { branches are } \\
\text { covered with } \\
\text { silver scales } \\
\text { that protect } \\
\text { against frost } \\
\text { and heat }\end{array}$ & $\begin{array}{c}\text { Long } \\
\text { branched } \\
\text { root, scaly } \\
\text { coating of } \\
\text { branches, an } \\
\text { alternate } \\
\text { arrangement } \\
\text { of foliage, } \\
\text { the silver } \\
\text { coating on } \\
\text { the bark and } \\
\text { leaves. The } \\
\text { root shape } \\
\text { can become } \\
\text { the } \\
\text { prototype of } \\
\text { the base of } \\
\text { the object, } \\
\text { the structure } \\
\text { of the } \\
\text { branches is } \\
\text { suitable for }\end{array}$ & $\begin{array}{l}\text { Reflection of } \\
\text { light, } \\
\text { protection } \\
\text { from cold } \\
\text { and heat, } \\
\text { additional } \\
\text { air spaces } \\
\text { that protect } \\
\text { against } \\
\text { temperature } \\
\text { extremes, } \\
\text { the creation } \\
\text { of scaly } \\
\text { facades with } \\
\text { high thermal } \\
\text { characteristi } \\
\text { cs. Silver } \\
\text { color in the } \\
\text { form of } \\
\text { spraying - } \\
\text { reflective } \\
\text { factor }\end{array}$ \\
\hline
\end{tabular}




\begin{tabular}{|c|c|c|c|c|}
\hline \multirow[t]{2}{*}{ Namelimage } & $\begin{array}{l}\text { Nature } \\
\text { of the } \\
\text { place }\end{array}$ & $\begin{array}{c}\text { Adaptation } \\
\text { characteristi } \\
\text { cs } \\
\end{array}$ & $\begin{array}{c}\text { Structure / } \\
\text { Architectur } \\
\text { al Form } \\
\end{array}$ & $\begin{array}{l}\text { Innovative } \\
\text { technologies }\end{array}$ \\
\hline & & & $\begin{array}{l}\text { the planning } \\
\text { structure }\end{array}$ & \\
\hline $\begin{array}{l}\text { Thistle. Biennial plant in the form of a } \\
\text { long stem with thorns. The flower is a } \\
\text { small fluffy bud, purple. [10]. }\end{array}$ & & $\begin{array}{l}\text { It grows in } \\
\text { the steppe } \\
\text { zone on } \\
\text { sandy clay } \\
\text { soils. } \\
\text { Thin leaves } \\
\text { and color } \\
\text { reflect } \\
\text { sunlight well. }\end{array}$ & $\begin{array}{c}\text { It has a long } \\
\text { stem, strewn } \\
\text { with thorns } \\
\text { with leaves } \\
\text { arranged } \\
\text { alternately } \\
\text { which can } \\
\text { be } \\
\text { interpreted } \\
\text { in } \\
\text { collapsible } \\
\text { structures. }\end{array}$ & $\begin{array}{l}\text { Sun- } \\
\text { protection } \\
\text { devices in } \\
\text { the form of a } \\
\text { prickly } \\
\text { frame of the } \\
\text { stem, } \\
\text { rhythmic } \\
\text { arrangement } \\
\text { of leaves - } \\
\text { water } \\
\text { conservation } \\
\text {. Fluffy } \\
\text { inflorescenc } \\
\text { e protects } \\
\text { against wind } \\
\text { and sun. }\end{array}$ \\
\hline \multicolumn{5}{|c|}{ Floodplain and marine plants } \\
\hline $\begin{array}{c}\text { Lotus. A large water lily, the petals, } \\
\text { and leaves of which are covered } \\
\text { with a wax coating, so that they do } \\
\text { not get wet and always remain above } \\
\text { the water. Lotus flowers in diameter } \\
\text { can reach up to } 30 \mathrm{~cm} \text {, there are pink } \\
{[10] .}\end{array}$ & $\begin{array}{l}\text { It grows } \\
\text { along the } \\
\text { banks of } \\
\text { water } \\
\text { bodies. In } \\
\text { water, } \\
\text { along } \\
\text { swampy } \\
\text { shores, } \\
\text { swamps. } \\
\text { often } \\
\text { forming } \\
\text { dense } \\
\text { thickets }\end{array}$ & $\begin{array}{l}\text { Main habitat } \\
\text { is the aquatic } \\
\text { environment, } \\
\text { warm } \\
\text { stagnant } \\
\text { water bodies. } \\
\text { The stems } \\
\text { are sunk deep } \\
\text { underwater } \\
\text { in the } \\
\text { ground. } \\
\text { The lotus } \\
\text { fruit is inside } \\
\text { the flower } \\
\text { and has the } \\
\text { shape of a } \\
\text { cone with an } \\
\text { opening so } \\
\text { that the fetus } \\
\text { can breathe }\end{array}$ & $\begin{array}{l}\text { Shape of the } \\
\text { flower and } \\
\text { the fruit is } \\
\text { harmonious } \\
\text { for creating } \\
\text { arbors and } \\
\text { small } \\
\text { architectural } \\
\text { forms }\end{array}$ & $\begin{array}{l}\text { Shape of the } \\
\text { leaves is } \\
\text { flexible and } \\
\text { with a large } \\
\text { area - the } \\
\text { ability to } \\
\text { create spatial } \\
\text { structures } \\
\text { for } \\
\text { protection } \\
\text { from the } \\
\text { sun. Coating } \\
\text { leaves } \\
\text { allows you } \\
\text { to recognize } \\
\text { water } \\
\text { repellent } \\
\text { compounds } \\
\text { for wall } \\
\text { surfaces and } \\
\text { facade } \\
\text { solutions }\end{array}$ \\
\hline
\end{tabular}




\begin{tabular}{|c|c|c|c|c|}
\hline elimage & $\begin{array}{c}\text { Nature } \\
\text { of the } \\
\text { place }\end{array}$ & $\begin{array}{c}\text { Adaptation } \\
\text { characteristi } \\
\text { cs } \\
\end{array}$ & $\begin{array}{c}\text { Structure / } \\
\text { Architectur } \\
\text { al Form }\end{array}$ & $\begin{array}{l}\text { Innovative } \\
\text { technologies }\end{array}$ \\
\hline $\begin{array}{r}\text { Reeds. Perenni } \\
250 \mathrm{~cm} \text {, with } \\
\text { rhiz }\end{array}$ & $\begin{array}{l}\text { Lake } \\
\text { reeds } \\
\text { grow on } \\
\text { the banks } \\
\text { of water } \\
\text { bodies. In } \\
\text { water, } \\
\text { along } \\
\text { swampy } \\
\text { shores, } \\
\text { swamps. } \\
\text { often } \\
\text { forming } \\
\text { dense } \\
\text { thickets. }\end{array}$ & $\begin{array}{c}\text { Flexible } \\
\text { straight stalk, } \\
\text { hollow } \\
\text { inside, } \\
\text { Inflorescence } \\
\text { corymbose- } \\
\text { paniculate, } \\
\text { rarely } \\
\text { compressed, } \\
\text { resembles a } \\
\text { brush of } \\
\text { prickly } \\
\text { spikelet. }\end{array}$ & $\begin{array}{c}\text { Paniculate } \\
\text { inflorescenc } \\
\text { es make it } \\
\text { possible to } \\
\text { use form } \\
\text { and } \\
\text { structure for } \\
\text { solving } \\
\text { small } \\
\text { architectural } \\
\text { forms - } \\
\text { shadow } \\
\text { canopies. }\end{array}$ & $\begin{array}{c}\text { Sun } \\
\text { protection } \\
\text { due to a } \\
\text { dense bowl- } \\
\text { shaped } \\
\text { coating } \\
\text { (protective } \\
\text { front } \\
\text { screens). }\end{array}$ \\
\hline $\begin{array}{c}\text { Sparganium - perennials with } \\
\text { flattened creeping rhizome, rooting } \\
\text { in nodes. The stems are flattened, } \\
\text { branched, with two rows of narrow } \\
\text { leaves. The fruits are hollow and can } \\
\text { float. [10]. }\end{array}$ & $\begin{array}{l}\text { Mostly } \\
\text { live in } \\
\text { shallow } \\
\text { water or } \\
\text { at a depth } \\
\text { of } 1-4 \mathrm{~m} \text {, } \\
\text { on a soft } \\
\text { sandy or } \\
\text { silty } \\
\text { bottom in } \\
\text { the calm } \\
\text { waters of } \\
\text { bays and } \\
\text { bays. }\end{array}$ & $\begin{array}{l}\text { Rhizomes are } \\
\text { monopodial, } \\
\text { which allows } \\
\text { the plant to } \\
\text { hold firmly } \\
\text { in conditions } \\
\text { of rapid flow. } \\
\text { Narrow } \\
\text { leaves have a } \\
\text { small area, } \\
\text { due to which } \\
\text { they retain } \\
\text { moisture. }\end{array}$ & $\begin{array}{c}\text { The } \\
\text { structure of } \\
\text { the leaf and } \\
\text { stem allows } \\
\text { the } \\
\text { formation of } \\
\text { supporting } \\
\text { structures of } \\
\text { architectural } \\
\text { elements. }\end{array}$ & $\begin{array}{l}\text { Inflorescenc } \\
\text { es fleshy } \\
\text { needle } \\
\text { accumulate } \\
\text { moisture, } \\
\text { similar to the } \\
\text { reservoir. }\end{array}$ \\
\hline $\begin{array}{l}\text { Rapa natans. Smooth oval or } \\
\text { diamond-shaped leaves have teeth } \\
\text { along the edges and resemble birch } \\
\text { leaves. Linear leaves, located } \\
\text { opposite each other, are formed on a } \\
\text { stem underwater [10]. }\end{array}$ & $\begin{array}{c}\text { Rapa } \\
\text { natans is } \\
\text { also } \\
\text { common } \\
\text { in lakes } \\
\text { with } \\
\text { stagnant } \\
\text { water and } \\
\text { swamps, } \\
\text { floodplain } \\
\text { s of small } \\
\text { freshwate } \\
\text { r rivers } \\
\text { with silt }\end{array}$ & $\begin{array}{l}\text { The stem of } \\
\text { the plant has } \\
2 \text { types of } \\
\text { leaves. The } \\
\text { second type } \\
\text { of leaf } \\
\text { resembles a } \\
\text { multi-tiered } \\
\text { outlet located } \\
\text { on the } \\
\text { surface of the } \\
\text { water. If the } \\
\text { water level } \\
\text { suddenly }\end{array}$ & $\begin{array}{c}\text { The } \\
\text { structure of } \\
\text { the outlet } \\
\text { allows you } \\
\text { to use a } \\
\text { similar } \\
\text { shape in } \\
\text { canopies, } \\
\text { decorative } \\
\text { elements, } \\
\text { tiles }\end{array}$ & $\begin{array}{c}\text { During } \\
\text { ripening, air } \\
\text { voids or } \\
\text { swimming } \\
\text { bubbles } \\
\text { appear on } \\
\text { their surface, } \\
\text { due to which } \\
\text { the outlet } \\
\text { can stay on } \\
\text { the surface } \\
\text { of the water. } \\
\text { The } \\
\text { principle of }\end{array}$ \\
\hline
\end{tabular}




\begin{tabular}{|c|c|c|c|c|}
\hline Namelimage & $\begin{array}{c}\text { Nature } \\
\text { of the } \\
\text { place }\end{array}$ & $\begin{array}{c}\text { Adaptation } \\
\text { characteristi } \\
\text { cs }\end{array}$ & $\begin{array}{l}\text { Structure / } \\
\text { Architectur } \\
\text { al Form }\end{array}$ & $\begin{array}{c}\text { Innovative } \\
\text { technologies }\end{array}$ \\
\hline & bottomed. & $\begin{array}{l}\text { rises, then } \\
\text { the stem is } \\
\text { separated } \\
\text { from the } \\
\text { bottom and } \\
\text { continues its } \\
\text { development } \\
\text { in the aquatic } \\
\text { environment. }\end{array}$ & & $\begin{array}{c}\text { creating } \\
\text { architectural } \\
\text { and } \\
\text { engineering } \\
\text { structures on } \\
\text { the water. }\end{array}$ \\
\hline
\end{tabular}

Another side of the bio model study is the consideration of innovative engineering technologies that lay the foundation for sustainable development of the designed environmental design objects. In the Astrakhan region, adaptive reactions of plants are very characteristic - the basis is protection from the sun, wind (dust storms), and low water consumption, based on the ability to retain moisture. Each of the plants considered has its own unique adaptability, which can be used to form an eco-model. Sun protection Interwoven branches - wind protection - (formation of facade screens in the corresponding structure). The structure of the leaves retains moisture - this is the ability to create structural panels for cooling facades. The shape of the flowers creates a shadow and protects the plant from the scorching sun - these are options for creating sunscreens. Reflection of light, protection from cold and heat, additional air spaces that protect from temperature extremes are options for creating scaly facades with high thermal characteristics. Silver color in the form of spraying is an additional reflective factor for architectural objects.

The third step is the search for designs. Organisms had to come up with mechanisms to ensure their needs in the most favorable way in their environment. Humankind learns to develop territories like plants and faces similar problems. Nowadays, engineers, thinking through designs, pose the same tasks designed to be economical, easy to manufacture, intellectually oriented with the ability to evolve and recover.

The most necessary link in the search for unique solutions is structural components, which include the possibility of fixing natural relationships with each other, for example: providing bearing capacity with a stalk of a massive crown or trellised structure of plants, or plant nodal joints of branches that could allow significant elongation to be invented with non-standard building solutions. That is the transformation of a bio model or its fragment into a geometric model, responsible for performing the necessary function. Next, it is necessary to conduct test tests of the obtained geometric model, which determines the positive aspects, the correspondence with previously advanced hypotheses and the nature of the use of prototypes, the search for negative aspects, and the refinement of the model to 
the desired level. It is also necessary to carry out computational and graphics calculations of a geometric model with the creation of drawing documentation and a real sample of a structural element.

In view of the developed design, its appearance largely decides on the final artistic image of the constructed object, with identical copying of volumes of nature, for example, in structures of small architectural forms, the design is isolated from the total volume of the bio model and supplemented with necessary functions, preserving the natural artistic image.

The viewer perceives the space, building it in detail from separate elements that accentuate attention or are the background. New unusual forms make the architectural space specific to perception, actively affect the human psyche. These are spatial constructions that possess not only expressiveness of the image, but also properties that contribute to the formation of urban space [11]. Light spatial shells can protect against direct exposure to solar radiation, create sufficient areas for relaxation in the shade, and due to the plasticity of the form, they can harmoniously fit into existing buildings.

Analysis of the spatial structure of plant-based Lotus and tamarisk identified the key characteristics of developed structures:

1. Design mobility (collapsible design);

2. Formation of internal semi-enclosed space;

3. The dynamism of space due to transformable structural elements;

4. Light shell on supports, a system of canopies that create a semi-closed space of recreation areas (the formation of shade on hot summer days, ensuring free ventilation);

5. Possibility of using landscaping.

Models of the developed spatial elements (awnings) are based on the analysis of prototypes, bioforms, the nature of their structure, life forms. During the study of plant formations, the principles of the organization of space in the conditions of adaptation to the climatic conditions of the Astrakhan region were revealed.

One example of such a transformation of the search for an ideological and artistic image based on the lotus bio model and the image of the water surface, expressed by the solution of the canopy system in a hot summer climate, at extremely high temperatures in the sun. The organization of half-closed space is achieved using lightweight collapsible structures, which are a rack-mount design with a significant area of the upper part, like a shoot and lotus leaves, and water surface, representing spatial structural elements, creating large areas for recreation and walks, protected from direct sunlight, free for ventilation, with the active use of landscaping (Fig. 1).

The question of the choice of material for manufacturing arises when identifying the volume and image of an object based on a bio model. The formation of organic architecture is based on the use of local building materials. The Astrakhan region is rich in deposits of natural materials: sand, limestone, gypsum, sand, clay and loam, natural dye - buffy clay.

The use of natural materials makes it possible to green the environment, saving it from products of the manufacturing industry, which has a detrimental effect on the environment, 
forming excessive overheating of the territory due to the absorption and transmission of solar energy, releasing impurities of chemical constituent elements into the atmosphere.

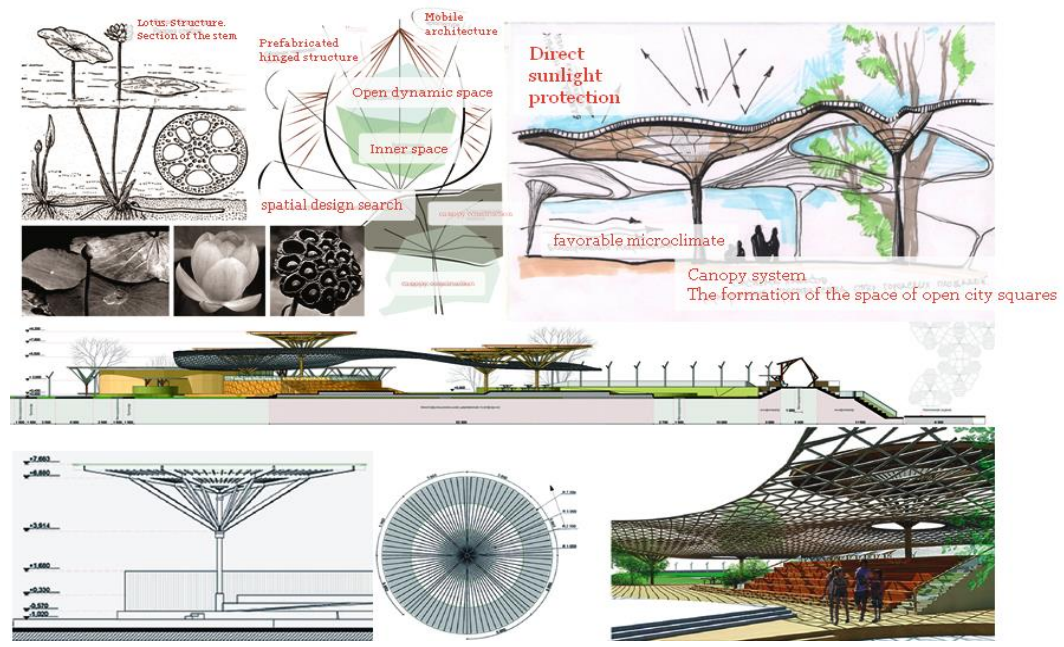

Fig. 1. Transformation of the search for an ideological and artistic image.

Because of the analysis of each natural material, their features are revealed, the nature of the surface, the building materials obtained on their basis, presented in Table 2 .

Table 2. Natural materials.

\begin{tabular}{|c|c|c|c|}
\hline $\begin{array}{c}\text { Natural } \\
\text { Material }\end{array}$ & General form & $\begin{array}{c}\text { Application / } \\
\text { Construction Materials }\end{array}$ & $\begin{array}{c}\text { Characteristics } \\
\text { Texture }\end{array}$ \\
\hline Clay & & $\begin{array}{c}\text { Ceramic } \\
\text { materials and products: } \\
\text { brick, roof tile, ceramic tile }\end{array}$ & $\begin{array}{c}\text { Light porous / } \\
\text { Matte / Opened (peeled) }\end{array}$ \\
\hline Sand & & $\begin{array}{l}\text { Decorative and construction work } \\
\text { (structural coatings), land } \\
\text { improvement/silicate products }\end{array}$ & $\begin{array}{l}\text { Bulk Grain Material / } \\
\text { Smooth, Rough, Matte }\end{array}$ \\
\hline Reeds & & $\begin{array}{c}\text { Ready construction material, reed } \\
\text { plate, wickerwork }\end{array}$ & $\begin{array}{l}\text { Lightweight durable } \\
\text { structure / } \\
\text { Grungy }\end{array}$ \\
\hline
\end{tabular}


An important component of the aesthetic aspect is the material, i.e. texture and texture that allows you to transform the plastic of an architectural object. Decisions of combinations of texture and texture based on the natural components of the Astrakhan region are extensive due to the characteristics of the region. The search for textures and textures can be defined in any element of nature. Consider, for example, the natural component of the earth's firmament to identify derivatives of textured surfaces and textures. Therefore, the firmament can be interpreted in various states due to soil composition and degree of moisture. Studying the coastal territory, we determine the texture in the form of a dense surface of sand grains, with a textured surface of wavy layers; clay soil dried in the sun receives a cracked texture surface; salt deposits give fancy ornaments on the clay surface, we get contrasting textures and textures.

The range of application of textures and textures is extensive, the competent use of surfaces will allow you to transform the existing environment and increase its visual aesthetic properties. A powerful effect on a person, together with the applied textures and textures, has a coloristic solution. The introduction of colors from the palette of natural components is proposed. [12]. Color for individual territorial regions will create color coding for urban spaces, which will allow introducing landmarks on Wednesday, increasing the recognition of territorial zoning and the attractiveness of recreational spaces and capital construction facilities of the city's large-scale ecosystem.

The solution of open recreational spaces in the natural gamut of the materials used will harmoniously link the fit objects with the landscape-environmental environment and will improve the quality of the video ecology of the environment. The natural component has a positive and relaxing effect on the psychoemotional state of a person, so a person's stay in such an environment will have a beneficial effect.

\section{Results}

The conducted climatic analysis revealed the main properties of the proposed eco-model. Such characteristics are sun-protection properties, wind, and dust-proof properties, moisture conservation, moisture consumption, resistance to strong winds, etc.

Each of these properties can be endowed with an appropriate structure and architectural appearance.

Sun-protection properties can be divided into several: direct protection from sunlight this is the form of awnings, visors, pergolas; and protection against overheating - this is the ability to save moisture, texture, surface color, materials used.

Wind and dust protection is the formation of a structure in the form of screens with the ability to trap or repel dust and self-clean.

Moisture conservation is the ability to accumulate moisture in tanks, to create cooling in a natural way, due to temperature differences (autonomously).

Moisture consumption is the possibility of recycling moisture, circulation in the building due to materials and their physical properties. 
Resistance to strong winds is the ability to pass wind through the structure of the object, structural solutions aimed at design flexibility and nodal, movable connection.

The study of bionic forms made it possible to determine the most characteristic forms for the region.

At the initial stage of modeling the architectural space of the city of Astrakhan, some characteristic forms of vegetation were chosen - Tamarix, silver goof, and lotus. The first stage of modeling is bionic practice, which includes naturalistic sketches. Graphic sketches that convey the design of the bionic form of the depicted plant were studied and performed; enlarged details were drawn and simplified to a geometric shape. By the example of sketches of Tamarix and lotus plants, the basic principles of building a natural form, structural design features were identified. The decorativeness of the fruits and inflorescences of the pine tree and Rapa natans, their elegant structure can form the basis for the development of a decorative ornament (graphic sketch of the fence lattice, ceramic tile).

After the study, the graphic and structural features of the objects in question were identified:

1. Identification of key characteristics;

2. Mobility of the structure;

3. Formation of internal semi-enclosed space;

4. The dynamism of space due to transformable elements.

Based on these features, small architectural forms are shown in Table 3.

The model of architectural space is a system of linearly interconnected elements. At the heart of this system is a bio model - this is the first landmark for the formation of ecological design for sustainable urban development.

The creation of the object is based on a bionic study of a bio model. The stages of the formation of environmental design:

1. Analysis of bio model features;

2. Innovative technologies;

3. Constructive solutions and spatial-geometric shaping;

4. Artistic image, the ideological-shaped formation of an architectural form;

5. Selection of building materials appropriate to the constructive solution (local natural resources);

6. Work with the invoice of materials;

7. Color scheme.

The environmental design model obtained because of a comprehensive study can become the basis for the development of a structural module - a spatially constructive element of improvement of the city's recreational areas or a full-fledged object operating autonomously.

Recreational areas of the city - a natural or specially organized area for recreation. Social processes of interaction take place in it; an organized environment should have a favorable psychological effect on a person. The territories of the natural landscape make up 
the ecological framework of the city [13]. Therefore, the reorganization of the architectural and planning decisions of the city, aimed at changing the spatial structure, will become the basis for improving the ecological condition of the city. A developed logically structured system of recreational areas, including the natural landscape in the city planning, will allow implementing an ecological approach to the formation of the architectural space. [14].

Elements of improvement - the main structural module for the formation of a recreation zone as an "eco niche" of urban space. These are small architectural forms, spatial structures (shells, awnings) designed based on biomodels.

The methods of architectural-bionic transformation of the form used in the modeling process allow you to embody images of the surrounding nature in architectural elements and objects. They make the city's architecture expressive, enhances its aesthetic qualities. The imagery transferred from nature surrounding the city to its architecture gradually forms such a concept as "city-style".

In addition to the design features identified during the geometric modeling of the biform, its ideological and artistic expressiveness, completeness and aesthetics are of great importance. Since a person perceives his environment primarily visually, and space has an effect on him. Therefore, an important step in creating a structural element of space based on bioforms is the art-shaped shaping, the desire for the expressiveness of the form and improve its aesthetic qualities. The studies are presented in Table 3.

Table 3. Formation of architectural forms based on bio models

\begin{tabular}{|c|c|c|c|c|}
\hline \multirow{3}{*}{ 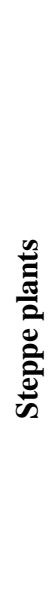 } & Name & $\begin{array}{c}\text { General } \\
\text { characteristics }\end{array}$ & Scheme & $\begin{array}{c}\text { Variants of the architectural } \\
\text { form }\end{array}$ \\
\hline & 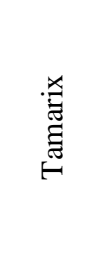 & $\begin{array}{l}\text { Flexible mobile } \\
\text { structure of the stems, } \\
\text { the presence of } \\
\text { emptiness protects } \\
\text { from the wind, retains } \\
\text { moisture, creates a } \\
\text { favorable microclimate }\end{array}$ & & \\
\hline & 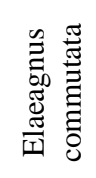 & $\begin{array}{l}\text { The trunk is uneven but } \\
\text { strong. The root system } \\
\text { is powerful and } \\
\text { branched }\end{array}$ & & \\
\hline
\end{tabular}




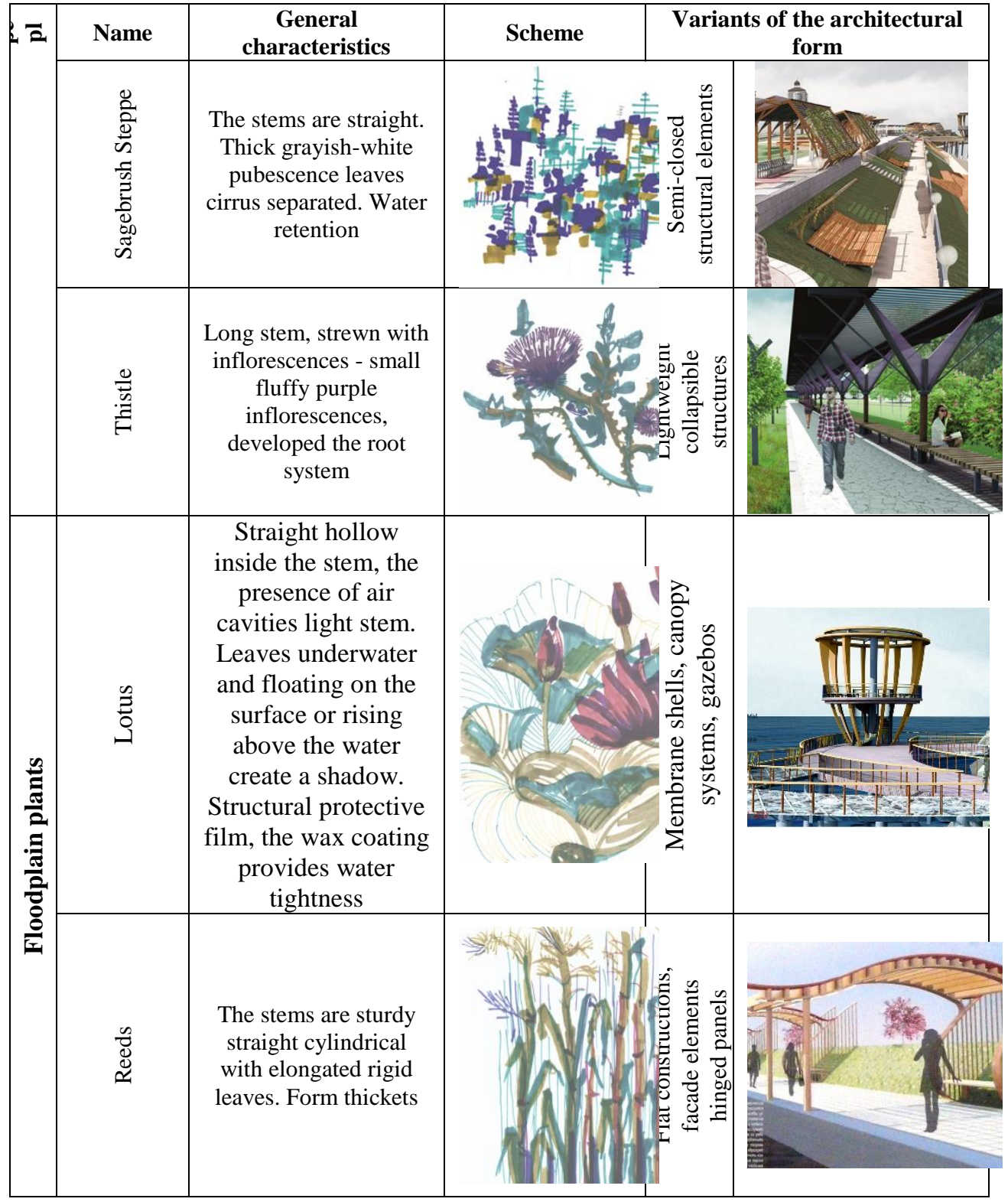




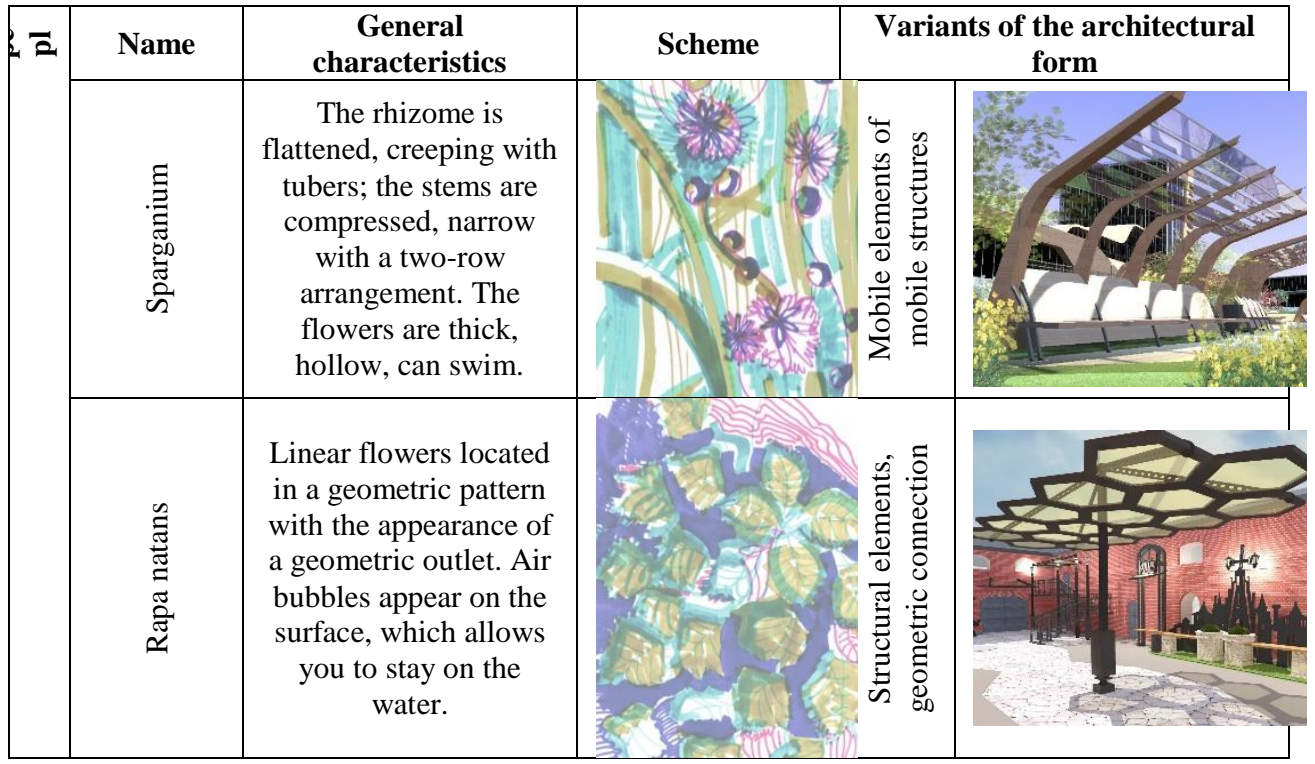

The result of a comprehensive environmental design of the environment will be the developed regional architectural style of the city of Astrakhan, emphasizing the importance of the connection between urban space and its living environment.

\section{Deliberations}

All the studies conducted to allow us to form a specific environment with historical and natural identity. The function is clearly correlated to climatic features:

Information communicated clearly, excluding various interpretations:

1. Statement of information natural form;

2. Identification of the appearance and internal structure formation (due to which features its morphogenesis is revealed).

3. How features are taken as the basis for the formation of an object.

4. The study will help to develop architectural objects that are harmoniously connected with the environment and create an urban environment comfortable and with its own characteristics.

\section{Conclusion}

Throughout all time, space is constantly changing, following the new traditions of human life and the development of modern technologies. "Urbanism is no longer just a process in 
which people pull themselves together in a place called a city and integrate into its system of life," wrote Louis Wirth [15]. Almost all the great thinkers saw a solution to the problem of organizing human settlements, searching for the ideal model for arranging a human home in collaboration with nature, in borrowing its basic laws and principles. This will improve not only the state of the space inside the city but also weaken the negative impact on the ecosystem as a whole.

There are many environmental concepts and approaches to the organization of urban space [16]. The concept of creating a model of the architectural and ecological space, based on the application of the principles of architectural bionics, will make the most efficient use of the natural resources of the Astrakhan region. By correctly adapting the urban space to the peculiarities of the regional climate, on the example of how the plant world can easily do this, it is possible to solve key problems in the formation of the architectural and ecological space.

\section{References}

1. V.I. Iovlev, Ecological foundations of the formation of architectural space (on the example of the Urals). The dissertation of doctoral architecture (2008)

2. V.P. Zubov, Leonardo da Vinci, 350 (2008)

3. D. Baumeister, R. Tocke, J. Dwyer, S. Ritter, J. Benyus, Biomimicry Handbook: A Bank of Best Practices, 3.8, 280 (2013)

4. V.I. Iovlev, ACADEMIA. Archit. Const., № 1, 66-69 (2007)

5. V.I. Iovlev, Housing № 6, $24-25$ (2008)

6. V.A. Ilyichev, V.I. Kolchunov, A.V. Bersenev, A.L. Pozdnyakov, . RAASN, Academy No. 1 (2009)

7. T. V. Belko Natural factors in the design of the environment: Landscaping, architectural bionics, cities of the future (2012)

8. V. N. Pilipenko, M. V. Lozovskaya, V. I. Zakutnova, Red Book of the Astrakhan Region. - Astrakhan: Astrakhan State University, 413 (2014)

9. C. Jenks, The New Paradigm in Architecture: The Language of Post-modernism. New Haven, New Haven, CT: Yale UP (2002)

10. M.A. Crippa, A. Gaudi, About the influence of nature on architecture (2004)

11. V.V.Bakharev, E.L. Ryabova, The formation of the architectural and landscape space of a modern city: social and environmental aspects of the problem (2011)

12. L. Wirth, Urbanism as a way of life, 108 (2016)

13. D. A. Garcia, Sust. Cit. Soc., 108-117 (2017) 